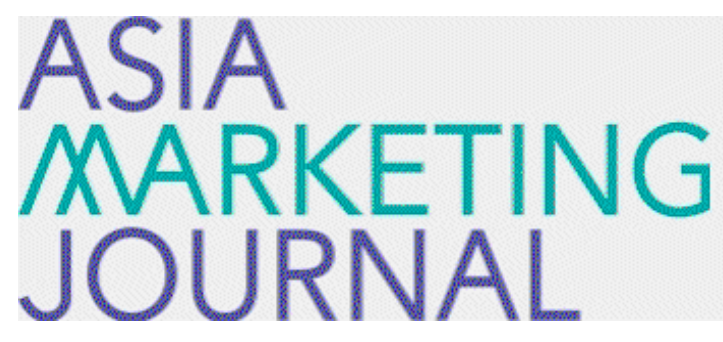

ASIA MARKETING JOURNAL

Volume 17 | Issue 1

Article 8

4-30-2015

\title{
KOREAN MARKETING ASSOCIATION 제17권 제1호 목차
}

Follow this and additional works at: https://amj.kma.re.kr/journal

Part of the Marketing Commons

\section{Recommended Citation}

(2015) "KOREAN MARKETING ASSOCIATION 제17권 제1호 목차," Asia Marketing Journal: Vol. 17 : Iss. 1 , Article 8.

Available at: https://doi.org/10.53728/2765-6500.1383

This Article is brought to you for free and open access by Asia Marketing Journal. It has been accepted for inclusion in Asia Marketing Journal by an authorized editor of Asia Marketing Journal. 


\section{ASAMARKEETNG JOURNAL}

\section{Vol. 17 No. 01 April 2015}

\section{<Research Paper>}

A Study on Green Consumer Segmentation Based on Socio-Demographics and Behavioral Responses: Renewing the Relationships between Socio-demographics and Green Behavior Young Doo Kim —

How to Build a Learning Capability for Innovation?

A Framework of Market-Based Learning Process Hyun Jung Lee $\cdot$ Jeong Eun Park Jae Hyun Pae

Can Brand Equity Explain Excess Behavioral Loyalty? Sang Uk Jung 55

The Lifespan of Social Hub In Social Networking Sites:

The Role of Reciprocity, Local Dominance and Social Interaction

Effects of Temporal Distance on Brand Extension Evaluation:

Applying the Construal-Level Perspective to Brand Extensions Kiwan Park

Sales Control Systems and Behavioral Responses: Mediating Role of

Regulatory Focus and Moderating Role of P-O Fit Jaewon Yoo 123

Consumer Reactions to Products of Social Enterprises:

An Application of the Stereotype Content Model 